\title{
APPARENT INHIBITION OF LIVER INSULINASE ACTIVITY BY SERUM AND SERUM FRACTIONS CONTAINING INSULIN- BINDING ANTIBODY
}

\author{
By ROSALYN S. YALOW AND SOLOMON A. BERSON
}

\author{
(From the Radioisotope Service of the Veterans Administration Hospital, Bronx, N. Y.)
}

(Submitted for publication October 10, 1956; accepted January 10, 1957)

A number of anti-insulin factors present in the serum of insulin-resistant subjects has been reported. Lowell (1) presented evidence for both insulin-neutralizing and insulin-sensitizing antibodies. De Fillipis and Iannaccone (2) and Colwell and Weiger (3) employing salting out methods and Sehon, Kaye, McGarry, and Rose (4) using starch electrophoresis have reported that insulin-neutralizing activity is localized in the $\gamma$ globulin fraction of the serum. Loveless and Cann (5), utilizing the technique of electrophoresis convection, observed that insulin-blocking antibody is present in the $\gamma$ globulin.fraction while insulin-sensitizing antibody is recovered with the $\beta$ globulins. An anti-insulin factor, capable of inhibiting glycogen accumulation by the isolated rat diaphragm, was reported by Field and Stetten (6) to be present in the $\alpha$ and $\beta$ globulin fraction of the serum of diabetic subjects, during episodes of severe insulin-resistant acidosis.

In addition to the factors reported in cases of insulin resistance, an insulin-binding antibody has been demonstrated, by zone electrophoresis and ultracentrifugal fractionation studies employing insulin- $\mathrm{I}^{131}$, to be present consistently in the serum of insulin treated subjects $(7,8)$. A study of the distribution of insulin-binding antibody among serum fractions separated with cold ethanol revealed that antibody was restricted to fraction I + III (which is comprised chiefly of $\beta$ and $\alpha$ globulins) in most subjects (9). In some, antibody was recovered in fraction II (primarily $\gamma$ globulins with a small amount of $\beta_{2}$ globulin) as well as in fraction I + III. In two subjects there were observed a small amount of insulin binding in fraction IV - VI (mainly albumin with a small amount of $\beta$ and $\alpha$ globulins) as well as more marked binding in the other two fractions. In all cases, bound insulin migrated in the inter $\gamma-\beta$ region on electrophoresis, regardless of the fraction in which the antibody was recovered (9).
Still another anti-insulin effect is manifested by some sera in inhibiting the degradation of insulin by rat liver homogenates. Williams (10) has recently reported that such inhibition is exhibited by normal plasma but that inhibition is much greater with diabetic than with normal sera.

The different methods employed in the demonstration of anti-insulin factors and in the fractionation of serum for their localization have made it impossible to clearly differentiate among these factors. In the present study the plasma factor associated with apparent inhibition of liver insulinase has been identified with insulin-binding antibody. Inhibitory activity was not observed in normal plasma or in plasma of diabetic subjects who had never received exogenous insulin. The apparent inhibition of liver insulinase activity described in the present report is clearly to be distinguished from that due to direct interference with the liver insulinase system. Inhibition in the present sense applies solely to the protection of insulin from the degrading action of liver insulinase as a consequence of the binding of insulin by insulinbinding antibody.

\section{METHODS}

Insulin- ${ }^{131}$ was prepared from crystalline beef insulin ${ }^{1}$ with a specific activity of $3-12$ mc. $\mathrm{I}^{131}$ per $\mathrm{mg}$. insulin and protected from extensive irradiation damage (11) according to methods previously described (9). At the higher specific activities, it was not possible to prevent such damage completely and 3 to 5 per cent was frequently found to be altered. Radiation-damaged material binds more or less indiscriminately to all the proteins of control plasma (8). The extent of binding of damaged material is independent of the concentration of insulin and is identical in all control plasma samples.

Serum protein fractions II, I + III, and IV - VI were prepared according to the method of Lever and associates (12) and concentrated, by freeze-drying, to two mil-

1 We are indebted to Dr. O. K. Behrens and Dr. C. W. Pettinga of Eli Lilly Co. for a generous supply of crystalline beef insulin Lot No. 535664 . 
liliter volumes before or after dialysis against 0.25 per cent $\mathrm{NaCl}$ and were then dialyzed against $0.067 \mathrm{M}$ phos-

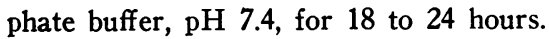

Liver homogenates were prepared by mincing fresh pieces of rat liver with two volumes of $0.067 \mathrm{M}$ phosphate buffer in a Virtis homogenizer. Following centrifugation for 5 minutes at $2,000 \mathrm{~g}$, the supernatant material was employed without further dilution or diluted $1: 10$ with the phosphate buffer. Where necessary, $\mathrm{pH}$ was again adjusted to 7.4 .

The extent of binding of insulin by serum antibody was determined by paper electrophoresis or hydrodynamic flow paper chromatography, employing insulin- $\mathrm{I}^{\mathbf{1 3 1}}$, according to methods described elsewhere (8). When insulin- $\mathrm{I}^{\mathbf{1 3 1}}$ is added to serum or serum protein fractions and subjected to electrophoresis or chromatography on paper, insulin which is not bound to any of the proteins is adsorbed to the paper at the site of application ("origin") $(13,7,8)$ but insulin which is bound to any of the proteins migrates away from the origin along with the binding protein. Since some dissociation of the insulinantibody complex may occur during the time required to complete electrophoresis, the presence or absence of binding in specific fractions was frequently determined by simple hydrodynamic flow chromatography (8), which effects satisfactory movement of the plasma proteins away from the origin in 20 to 30 minutes.

\section{Experimental procedures}

Uninhibited reaction. Insulin concentrations ranging from 0.2 to $500 \mu \mathrm{g}$. per $\mathrm{ml}$. were prepared in solutions of $0.067 \mathrm{M}$ phosphate buffer containing serum albumin, 25 to $50 \mathrm{mg}$. per $\mathrm{ml}$., for the purpose of minimizing adsorption of insulin to the walls of glass containers (14). Tracer insulin- $\mathrm{I}^{131}$ containing 400 millimicrograms insulin was added to each solution and was taken into account in calculation of the total insulin concentration.

Substrate solutions and preparations of liver homogenate were placed in a constant temperature water bath at $37^{\circ} \mathrm{C}$ and allowed to reach temperature equilibrium.

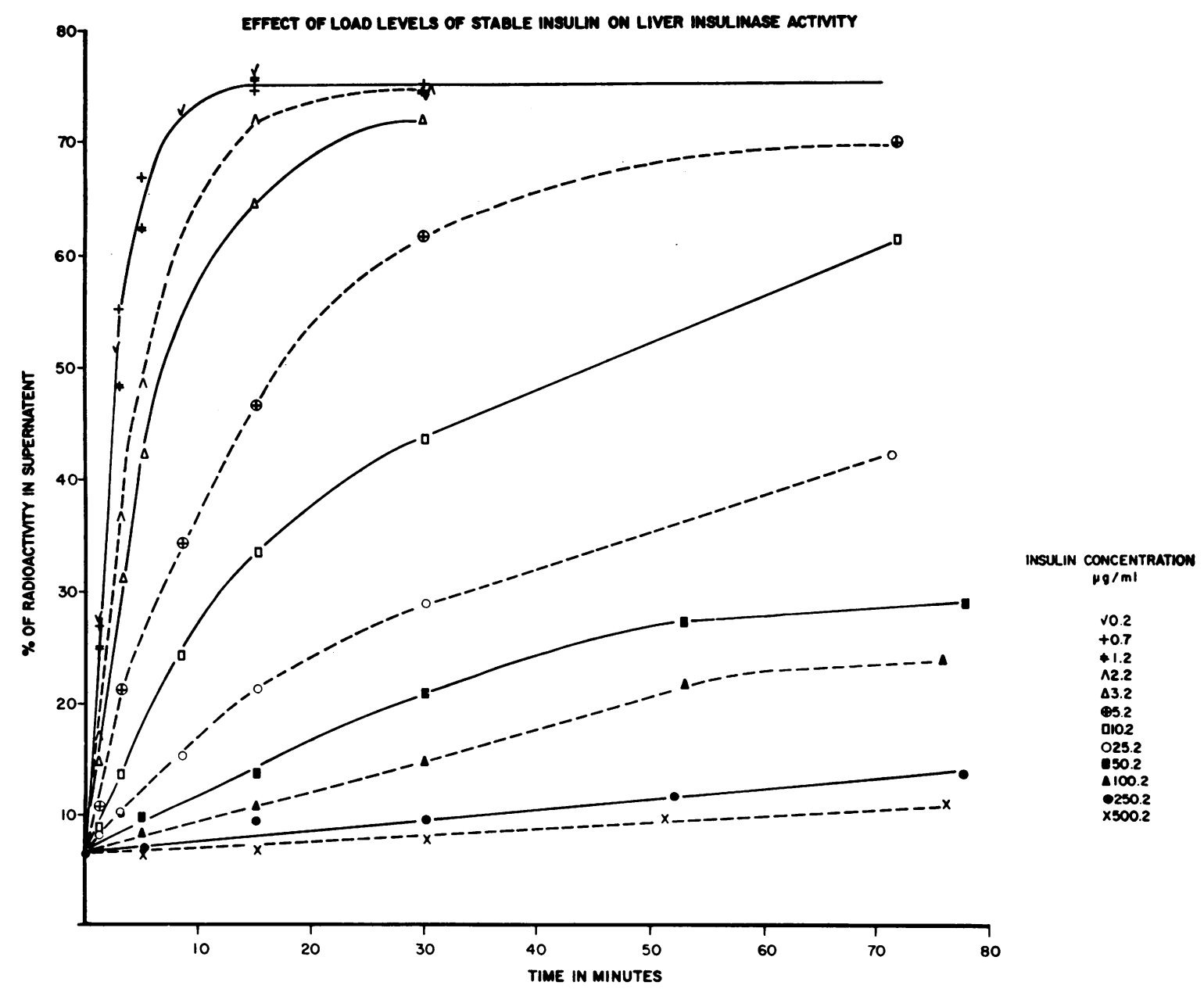

Fig. 1. Degradation of Insulin by Rat Liver Homogenate at Various Concentrations of Insulin Each substrate solution contained $0.2 \mu \mathrm{g}$. per $\mathrm{ml}$. insulin- $\mathrm{I}^{131}$. 


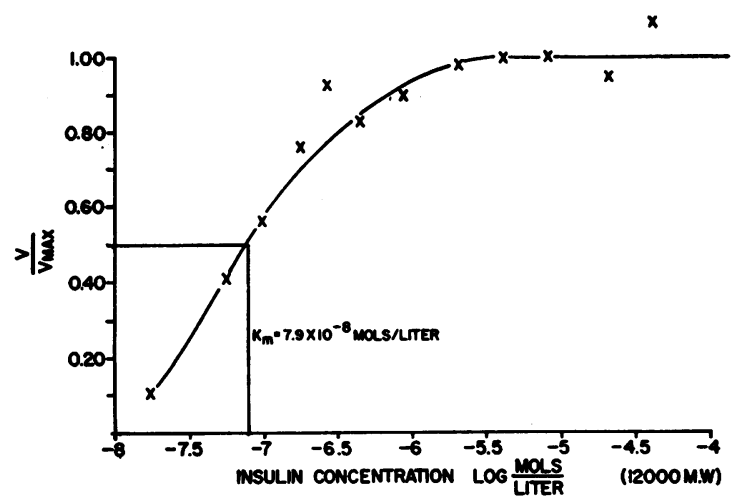

Fig. 2. Insulin Degradation (V/V $/ \mathrm{V}_{\max }$ ) as a Function of Substrate Concentration

One milliliter of a 1:10 dilution of liver homogenate was added to one milliliter substrate solution and mixed instantly. At various intervals, 0.1 or $0.2-\mathrm{ml}$. aliquots were removed and pipetted into test tubes containing $5 \mathrm{ml}$. cold 10 per cent trichloracetic acid. Precipitates and filtrates were assayed separately for radioactivity in a well scintillation counter with a sensitivity of $1.00 \times 10^{8} \mathrm{cpm}$. per $\mu$ c. $\mathrm{I}^{131}$ over a background of $200 \mathrm{cpm}$. Radioactivity in the filtrate was taken to represent degraded insulin- $\mathrm{I}^{131}$. It has been shown elsewhere (15) that degradation involves proteolytic activity and not simply the process of deiodination.

Inhibited reaction. Known amounts of insulin- $\mathrm{I}^{131}$ were added to 0.5 or $1.0 \mathrm{ml}$. of dialyzed whole serum, whole plasma or plasma fraction and incubated at $37^{\circ}$ for 30 minutes. Control solutions containing phosphate buffer, serum albumin, and insulin- $\mathrm{I}^{131}$ as described above were run simultaneously. Aliquots of all solutions were removed for electrophoretic or chromatographic analysis. One-tenth or $0.5 \mathrm{ml}$. undiluted liver homogenate, or 1.0 ml. of a 1:10 dilution of liver homogenate was then added to the substrate solutions and incubation at $37^{\circ} \mathrm{C}$ was continued. Aliquots were taken at various intervals and added to cold 10 per cent trichloracetic acid as described above. For any individual experiment, volumes and dilutions of liver homogenate employed were identical for all substrate solutions.

\section{RESULTS}

\section{Uninhibited reaction}

The fraction of insulin- $\mathrm{I}^{131}$ degraded as a function of time is plotted for various insulin concentrations in Figure 1. The initial velocity at each concentration was calculated from the product of the zero time slope and the initial insulin concentration and is plotted as fraction of the maximum velocity $v s$. substrate concentration in Figure 2. A Lineweaver-Burk plot (16) of the same data is presented in Figure 3. Assuming a molecular weight of 12,000 for insulin, the Michaelis-Menten constant $\left(K_{m}\right)$ for this reaction is $7.9 \times 10^{-8}$ mols per liter and $\mathrm{V}_{\max }$ is $2.50 \times 10^{-8}$ mols per minute. When account is taken of the dilution factor this amounts to $18 \mu \mathrm{g}$. min..$^{-1}$ per gram liver.

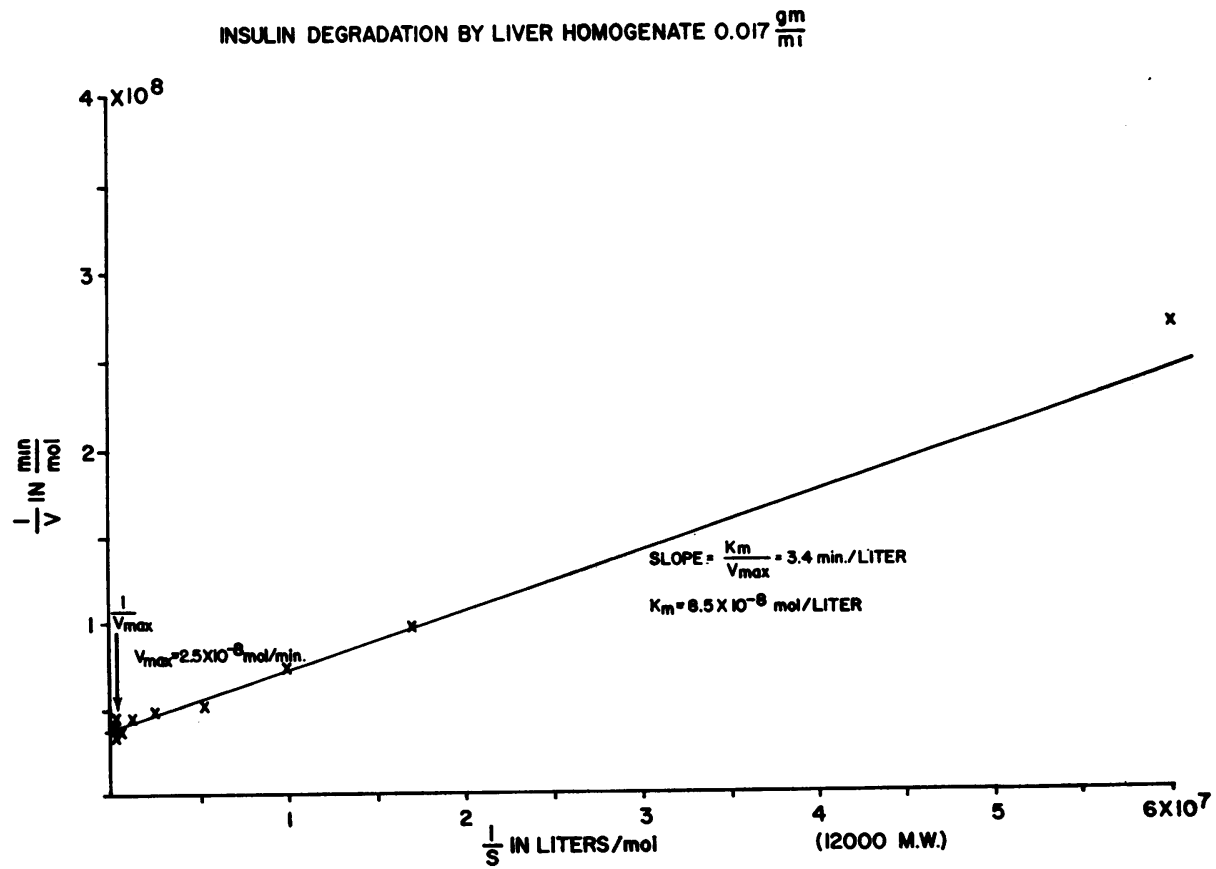

Fig. 3. Lineweaver-Burk Plot of Same Data as in Figure 2 


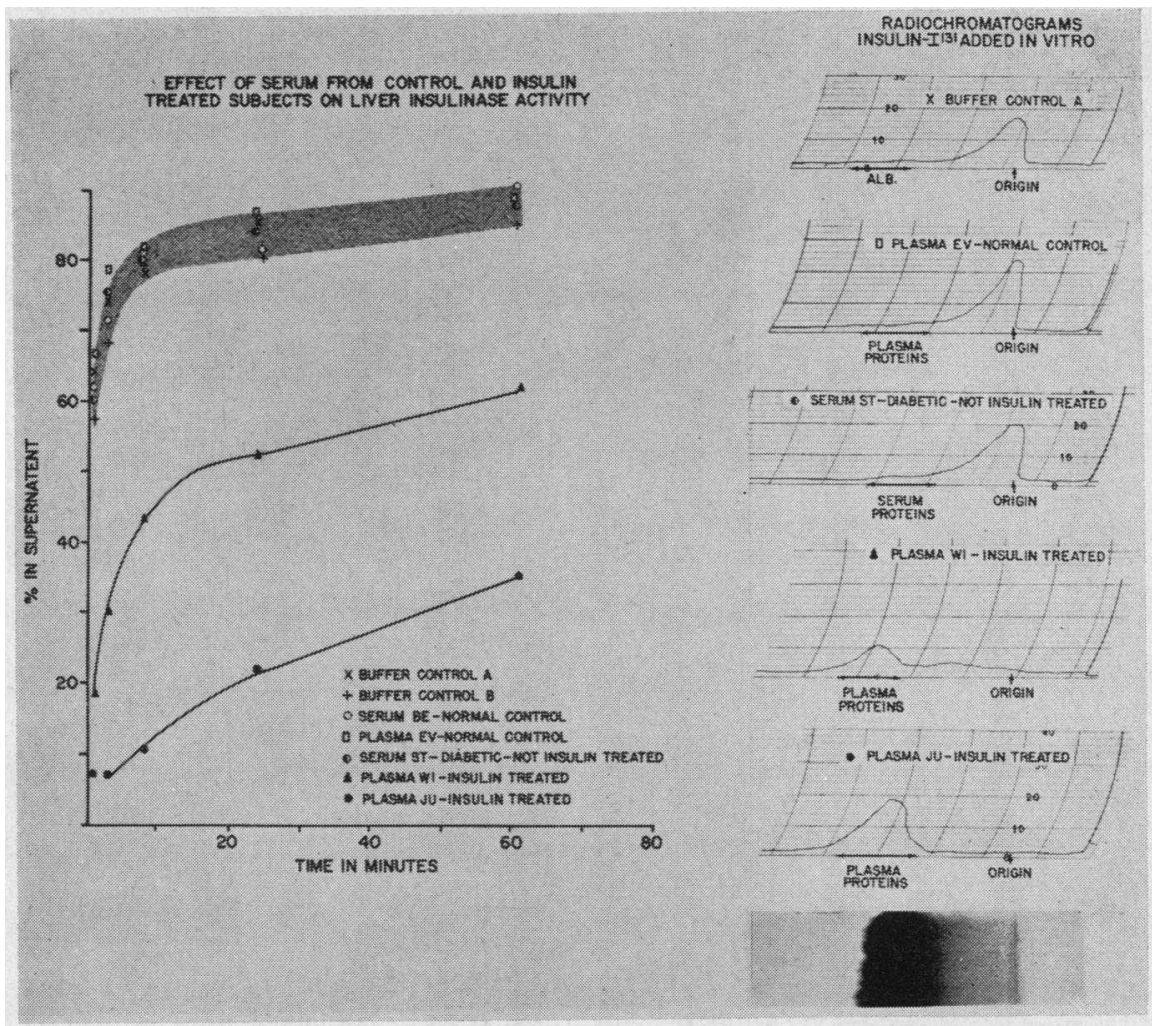

Fig. 4. The Effect of Serum and Plasma of Insulin Treated and Control Subjects on the Rate of Degradation of Insulin-I ${ }^{131}$ by Rat Liver Homogenates

The small fraction of radioactivity migrating with albumin in the buffer control studies and with the plasma protein of control subjects represents radiation damaged material (see text).

\section{Reaction with serum or plasma}

The serum or plasma of subjects (diabetic or nondiabetic) who had never received exogenous insulin revealed no evidence of insulin-binding on paper electrophoresis and chromatography and had no influence on the rate of degradation of insulin- $\mathrm{I}^{131}$ by liver insulinase (Figure 4 ).

In the presence of serum or plasma from insulin treated subjects, however, the rate of degradation of insulin- $\mathrm{I}^{131}$ was inhibited significantly (Figure 4). This inhibition was correlated with the presence of insulin binding as demonstrated by paper electrophoresis or chromatography (Figure 4). When insulin concentrations were increased, resulting in an increased fraction of unbound insulin, the per cent of insulin degraded as a function of time increased, in contrast to the decrease observed in the serum of nontreated subjects (Figure 5) and in the control solutions (Fig- ure 1). The inhibitory activity was correlated with the presence of electrophoretically demonstrable insulin binding to inter $\gamma-\beta$ globulins regardless of whether insulin therapy had been given for diabetes or schizophrenia.

\section{Reaction with plasma protein fractions}

Inhibition of liver insulinase activity corresponded precisely to the presence or absence of insulin binding by the specific fractions, as determined by paper electrophoresis or chromatography. In cases where insulin binding was observed only in fraction I + III, inhibition was observed only with this fraction (Figure 6). In those cases where insulin-binding antibody was present in fraction II as well as in fraction I + III (Figures $7,8)$, inhibition of liver insulinase activity was evident in both fractions and was roughly proportional to the degree of binding exhibited by each 


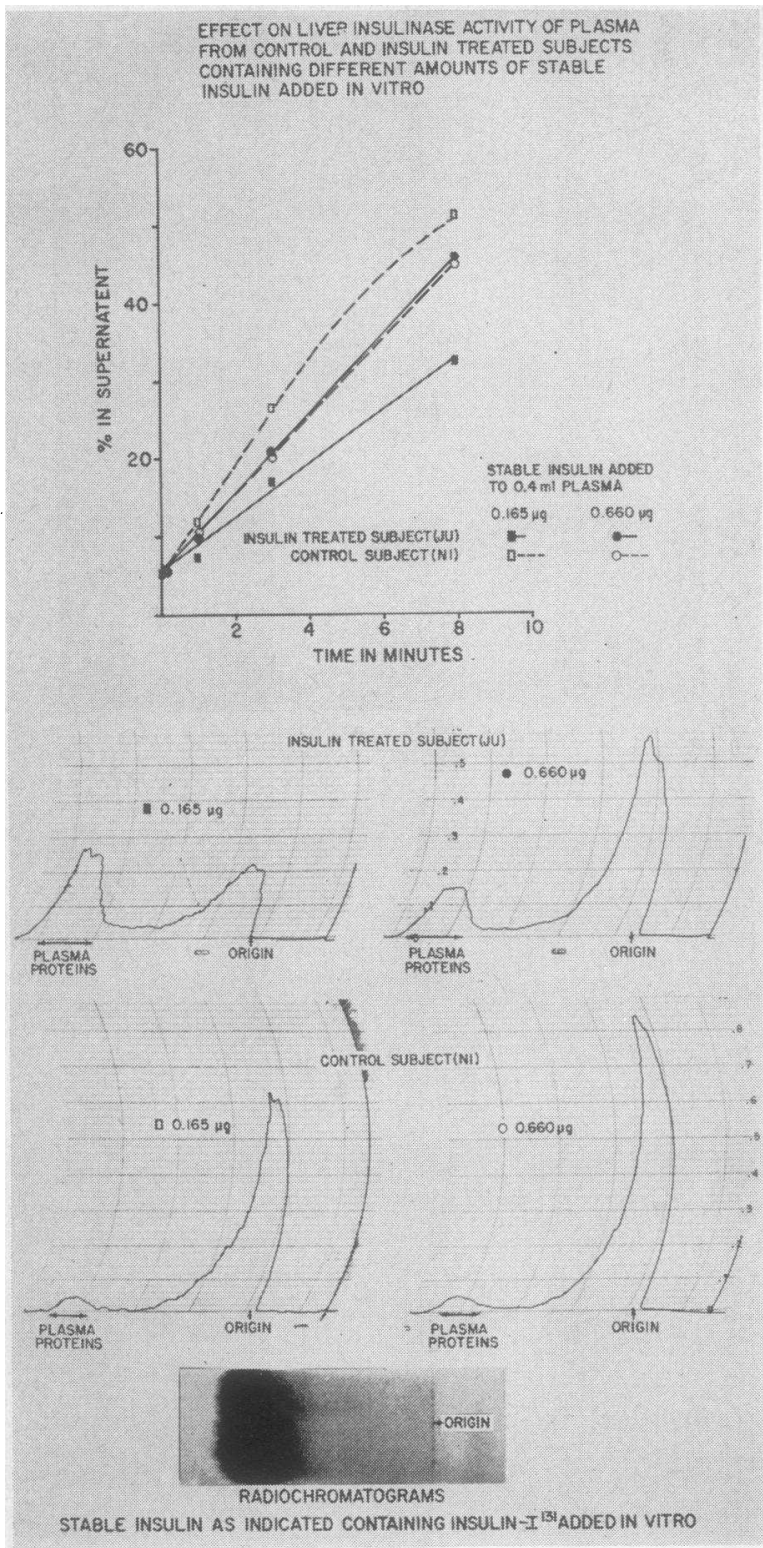

Fig. 5. The Effect of Varying Substrate Concentrations on the Rate of Degradation of INSUlin-I ${ }^{33}$ by Rat Liver Homogenate Incubated with Plasma of Control and Insulin Treated Subjects

Note the radiation damaged material migrating with the plasma proteins of the control subject.

fraction. In one case binding was present in all three fractions and all three fractions inhibited insulin degradation by the liver homogenates.

It has been observed previously (9) that, on one fractionation, insulin-binding antibody may be present in both fraction I + III and fraction II, but on a repeat fractionation of the same serum, antibody may be recovered only in fraction I + III.
In one such case studied here inhibitory activity was manifested by both II and I + III (Figure 7) when both fractions contained antibody and by fraction I + III alone when only that fraction contained antibody (Figure 6).

\section{DISCUSSION}

Mirsky, Perisutti, and Dixon (17) have previously made a thorough study of the rat liver insulinase system. The $\mathrm{V}_{\max }$ obtained in the present study (18 $\mu$ g. per min. per gram liver) is in good agreement with that $(20 \mu \mathrm{g}$. per min. per gram liver) obtained by these workers. However, their value for $\mathrm{K}_{\mathrm{m}}$ is over 100 times as great as that reported here. This discrepancy is probably explained by the fact that Mirsky, Perisutti, and Dixon (17) determined the extent of degradation at the end of 30 minutes and assumed that degradation was linear for all substrate concentrations during this time. The present observations (Figure 1) indicate that this procedure would markedly underestimate the velocities at the lower concentrations and would lead to a gross overestimate of the value for $\mathrm{K}_{\mathrm{m}}$.

The correspondence of demonstrable insulin binding and inhibition of liver insulinase activity indicates that the two manifestations of "antiinsulin" activity are identical. This conclusion is further strengthened by the observation that an increase in insulin concentration, which reduces the ratio of bound to unbound insulin, leads to an increase in the fractional rate of degradation. This observation would be difficult to reconcile with any interpretation that inhibition of liver insulinase activity is associated with some plasma factor unrelated to insulin binding such as "insulinase inhibitor," etc., for if this were the case, increase in substrate (insulin) concentration should lead to a decrease in the fractional rate of degradation.

These studies do not confirm the observation of Williams (10) that normal plasma inhibits the insulin degrading action of liver homogenates. A possible explanation for the difference in results may be related to the addition of serum albumin to control solutions in the studies reported here. When small amounts of tracer insulin- ${ }^{131}$ alone are incubated with phosphate buffer and liver homogenate, significant amounts of insulin- ${ }^{\mathbf{1 3 1}}$ continue to adsorb to the glass walls of the vessels during the experiment (18). Since the degraded 


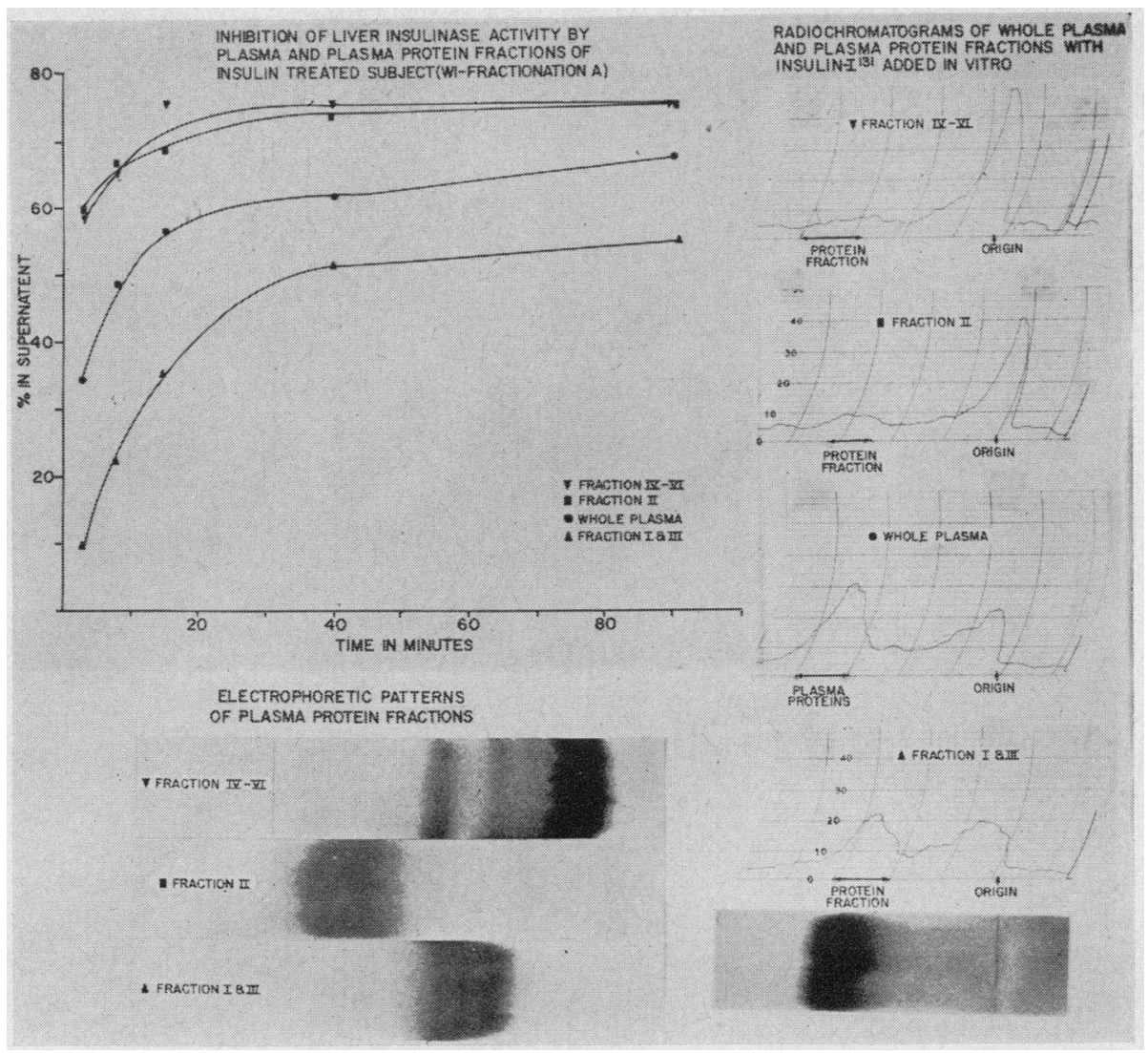

Fig. 6. The Effect of Plasma and Plasma Protein Fractions from an Insulin Treated Subject (Wi) on the Rate of Degradation of Insulin-I ${ }^{31}$ by Rat Liver Homogenate and Correlation with Chromatographic Evidence of the Presence or Absence of Insulin Binding

material is not adsorbed, the fraction of undegraded insulin remaining in solution at any time appears to be less than in the presence of serum or albumin, either of which serves to competitively inhibit insulin adsorption by the glass. The rate of degradation therefore appears to be inhibited by the presence of plasma.

Serum albumin itself has no inhibitory influence on liver insulinase activity $(10,17)$ nor do a number of other proteins (17). However, the competitively inhibitory effect on liver insulinase activity of certain other proteins such as glucagon (18) and the competitively inhibitory effect of insulin on liver "adrenocorticotropinase" and liver "glucagonase" activity (18) suggests that liver insulinase is not an absolutely specific enzyme system. The possibility that competitively inhibitory proteins are present in sufficiently high concentration to explain the results obtained in this study is unlikely and furthermore could not account for the increase in fractional rate of degradation with increase in insulin concentration in inhibitory sera.

The present study also fails to confirm the inhibitory influence of diabetic plasma unless the subject has received insulin therapy for some time and has produced insulin-binding antibody, since plasma of nontreated diabetic subjects contains no insulin-binding antibody and fails to inhibit insulinase activity.

The possibility of identity among some of the diverse anti-insulin activities reported by different investigators has been considered elsewhere (9). The present study indicates that at least two manifestations of "anti-insulin" activity are referable to the same phenomenon, namely binding of insulin by antibody. Whether insulin-neutralizing activity, reported to reside in the $\gamma$ globulin fraction $(2-4)$, is identical to insulin-binding globulin, which has been shown to have an elec- 

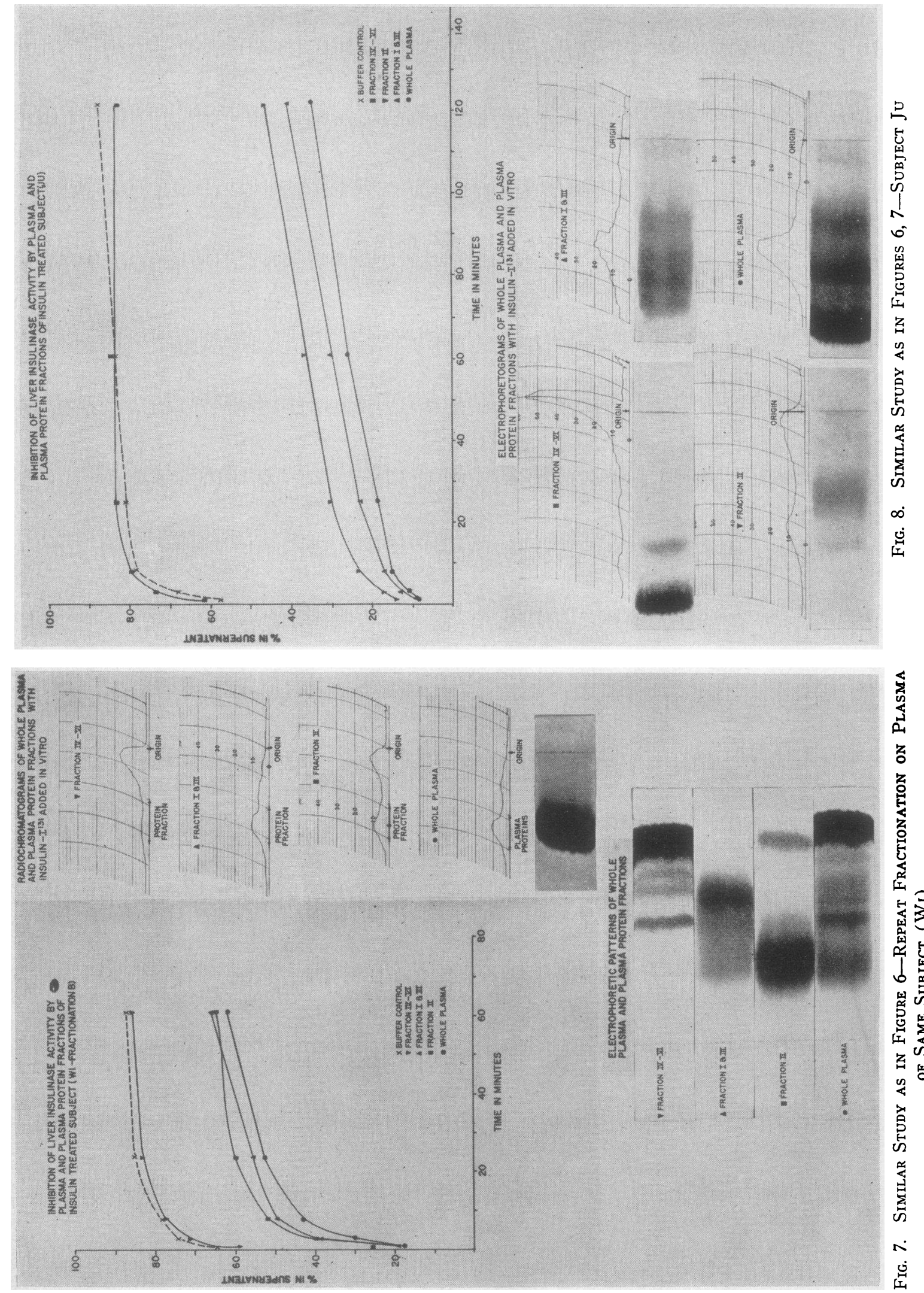
trophoretic mobility corresponding to the inter $\gamma-\beta$ region (9) cannot be answered at present. Examination of insulin-binding protein fractions for neutralizing activity appears indicated.

\section{SUMMARY AND CONCLUSION}

1. The kinetics of insulinase activity of rat liver homogenate preparations were studied employing insulin- $\mathrm{I}^{\mathbf{1 3 1}}$ as a tracer. $\mathrm{K}_{\mathrm{m}}$ for the reaction was $7.9 \times 10^{-8}$ mols per liter and $\mathrm{V}_{\max }$ was found to be $18 \mu \mathrm{g}$. per min. per gram liver at $37^{\circ}$ $\mathrm{C}$ and $\mathrm{pH} 7.4$.

2. Pre-incubation of insulin- $\mathrm{I}^{131}$ with plasma or serum of insulin-treated subjects resulted in inhibition of liver insulinase activity. No such inhibition was observed with serum or plasma of diabetic or nondiabetic subjects who had never been treated with insulin. Inhibition of liver insulinase activity was correlated with the presence of insulin-binding antibody as demonstrated by paper electrophoresis or paper chromatography.

3. When inhibitory sera were fractionated with cold ethanol, inhibitory activity of the specific fractions was correlated with the presence of insulin-binding antibody.

4. It is concluded that the apparent inhibition of liver insulinase activity by plasma or plasma fractions of insulin-treated subjects is due to the complexing of insulin by insulin-binding antibody.

\section{ACKNOWLEDGMENTS}

We wish to thank Mr. Manuel J. Villazon for the technical assistance in performing the ethanol fractionations. We also wish to thank Miss Eve Spelke and Mrs. Frieda Steiner for secretarial assistance.

\section{REFERENCES}

1. Lowell, F. C., Evidence for existence of two antibodies for crystalline insulin. Proc. Soc. Exper. Biol. \& Med., 1942, 50, 167.

2. De Filippis, V., and Iannaccone, A., Insulin-neutralising activity of gamma-globulins derived from the serum of an insulin-resistant patient. Lancet, 1952, 1, 1192.

3. Colwell, A. R., and Weiger, R. W., Inhibition of insulin action by serum gamma globulin. J. Lab. \& Clin. Med., 1956, 47, 844.
4. Sehon, A. H., Kaye, M., McGarry, E., and Rose, B., Localization of an insulin-neutralizing factor by zone electrophoresis in a serum of an insulin-resistant patient. J. Lab. \& Clin. Med., 1955, 45, 765.

5. Loveless, M. H., and Cann, J. R., Distribution of "blocking" antibody in human serum proteins fractionated by electrophoresis-convection. J. Immunol., 1955, 74, 329.

6. Field, J. B., and Stetten, D., Jr., Insulin antagonist activity of serum in diabetic acidosis. Federation Proc., 1956, 15, 250.

7. Berson, S. A., Yalow, R. S., Bauman, A., Rothschild, M. A., and Newerly, K., Persistence of I ${ }^{121}$-labeled insulin in the blood of insulin-treated subjects. (Abst.) Northwest Med., 1956, 55, 541.

8. Berson, S. A., Yalow, R. S., Bauman, A., Rothschild, M. A., and Newerly, K., Insulin- $\mathrm{I}^{132}$ metabolism in human subjects: Demonstration of insulin binding globulin in the circulation of insulin treated subjects. J. Clin. Invest., 1956, 35, 170.

9. Berson, S. A., and Yalow, R. S., Ethanol fractionation of plasma and electrophoretic identification of insulin-binding antibody. J. Clin. Invest., 1957, 36, 642.

10. Williams, R. H., Insulin distribution and degradation. Metabolism, 1956, 5, 128.

11. Yalow, R. S., and Berson, S. A., Effect of $x$-rays on trace-labeled $\mathrm{I}^{131}$-insulin and its relevance to biologic studies with $\mathrm{I}^{131}$-labeled proteins. Radiology, 1956, 66, 106.

12. Lever, W. F., Gurd, F. R. N., Uroma, E., Brown, R. K., Barnes, B. A., Schmid, K., and Schultz, E. L., Chemical, clinical, and immunological studies on the products of human plasma fractionation. XL. Quantitative separation and determination of the protein components in small amounts of normal human plasma. J. Clin. Invest., 1951, 30, 99.

13. Kallee, E., and Seybold, G., Über ${ }^{121} \mathrm{~J}$-signiertes Insulin III. (Verteilung im Rattenorganismus). Ztschr. f. Naturforsch., 1954, 9B, 307.

14. Ferrebee, J. W., Johnson, B. B., Mithoefer, J. C., and Gardella, J. W., Insulin and adrenocorticotropin labeled with radio-iodine. Endocrinology, 1951, 48, 277.

15. Berson, S. A., Yalow, R. S., and Volk, B. W., In vivo and in vitro metabolism of insulin- $\mathrm{I}^{131}$ and glucagon- $\mathrm{I}^{181}$ in normal rabbits and in cortisonetreated rabbits. J. Lab. \& Clin. Med., 1957, 49, 331.

16. Lineweaver, H., and Burk, D., The determination of enzyme dissociation constants. J. Am. Chem. Soc., 1934, 56, 658.

17. Mirsky, I. A., Perisutti, G., and Dixon, F. J., The destruction of $\mathrm{I}^{131}$-labeled insulin by rat liver extracts. J. Biol. Chem., 1955, 214, 397.

18. Berson, S. A., and Yalow, R. S., Unpublished observations. 